\title{
ACCESS TO HIGHER EDUCATION FOR UNDOCUMENTED AND “DACAMENTED” STUDENTS: THE CURRENT STATE OF AFFAIRS
}

\author{
Angela Adams* \\ Kerry S. Boyne**
}

\section{INTRODUCTION}

An estimated 11.5 million of the more than 40 million foreign-born individuals residing in the United States are considered "undocumented immigrants." ${ }^{1}$ Roughly 1.8 million of the nation's undocumented population is eighteen years old or younger, ${ }^{2}$ and an estimated 65,000 undocumented students graduate from American high schools each year. ${ }^{3}$ In light of the expansive undocumented youth population in the United States, on June 15, 2012, the Obama Administration authored the memorandum

\footnotetext{
*Angela D. Adams serves as Associate General Counsel for Immigration at Indiana University. Before joining Indiana University, Ms. Adams was a partner at Lewis \& Kappes, P.C. where she advised both employers and individuals on a broad range of immigration issues. Prior to joining Lewis \& Kappes, she served as an Education Consultant for the Division of Language Minority and Migrant Programs within the Indiana Department of Education. She currently serves as the Chair of the Indiana Chapter of the American Immigration Lawyers Association (AILA). Please note that the views, opinions and assumptions in this article are those of the author and do not necessarily reflect the official policy or position of Indiana University.

${ }^{* *}$ Kerry S. Boyne received her J.D. from Indiana University Maurer School of Law in 2012. Ms. Boyne works in the immigration field, assisting clients in acquisition of deferred action for childhood arrivals, family based immigrant visas, U visas, adjustment of status, asylum, consular processing, waivers of inadmissibility, and various forms of relief from removal.

1 Faye Hipsman \& Doris Meissner, Immigration in the United States: New Economic, Social, Political Landscapes with Legislative Reform on the Horizon, Migration Policy Inst. (Apr. 16, 2013), http://perma.cc/9D66-62W5. This term refers to those foreign born individuals residing in the United States without lawful immigration status.

${ }^{2}$ Vanessa Cárdenas \& Sophia Kerby, The State of Latinos in the United States, CTR. AM. Progress (Aug. 8, 2012), https://perma.cc/TLB2-QWSP.

${ }^{3}$ Catherine Eusebia \& Fermín Mendoza, Educators fOr Fair Education, The Case for Undocumented Students in Higher Education 5 (2013), available at http://perma.cc/UJM4-MR8E.
} 
Exercising Prosecutorial Discretion with Respect to Individuals Who Came to the United States as Children. ${ }^{4}$ This memorandum called for a new program referred to as Deferred Action for Childhood Arrivals ("DACA") and directed U.S. immigration authorities to withhold immigration enforcement against, and grant temporary relief to, many young undocumented individuals residing in the United States. When implemented, the DACA program represented a monumental change in our nation's immigration policies and stood to benefit an estimated 1.4 million undocumented youths in the United States. ${ }^{5}$ Since its inception approximately 642,685 individuals have applied for DACA, with more than 553,000 applications approved and several thousand still pending. ${ }^{6}$ On November 20, 2014, the President announced an expanded DACA which could stand to benefit an additional 300,000 people in the United States. ${ }^{7}$

The implementation of the DACA program has prompted new discourse regarding state laws and policies addressing access to postsecondary education for "DACAmented" 8 and undocumented students. A growing number of states have passed legislation and implemented policies allowing both DACA recipients and undocumented students to enroll in colleges and universities, and pay resident tuition rates at public institutions of higher education. With no federal law prohibiting postsecondary enrollment ${ }^{9}$ or resident tuition rates for DACA and undocumented students, ${ }^{10}$ states have been dealing with these questions in different and often inconsistent ways.

This article examines developments in federal and state laws and policies that have come into play over the last decade, providing an update to the 2005 publication of Higher Education for Undocumented Students:

\footnotetext{
${ }^{4}$ Memorandum from Sec'y of Homeland Sec. Janet Napolitano to David V. Aguilar, Acting Comm'r, U.S. Customs and Border Prot.; Alejandro Mayorkas, Director, U.S. Citizenship and Immigration Services; and John Morton, Director, U.S. Immigration and Customs Enforcement (June 15, 2012) [hereinafter

Napolitano Memorandum], available at http://perma.cc/R4C7-76SM.

5 Economic Benefits of Granting Deferred Action to Unauthorized Immigrants Brought to U.S. as Youth, IMMIGRATION POL'Y CTR. (June 22, 2012), http://perma.cc/W6FB-EABT.

6 U.S. CitIZENSHIP AND IMMigRATION SERVICES, NuMBER OF I-821D, CONSIDERATION OF DEFERRED ACTION FOR CHILDHOOD ARRIVALS BY FISCAL YeAR, QuARTER, InTAKE, BIOMETRICs AND CASE StATUS: 2012-2014 (2014), available at http://perma.cc/9W9B-TD3U.

7 See http://www.uscis.gov/immigrationaction\#daca for additional guidelines on expanded DACA program.

${ }^{8}$ A term often used to refer to DACA recipients, see Roberto G. Gonzales \& Angie M. Bautista-Chavez, Two Years and Counting: Assessing the Growing Power of DACA, IMMigRATION PoLICY CTR. (June 2014), http://perma.cc/Q2EF-QAWS.

${ }^{9}$ See discussion infra Part III.A.

10 See discussion infra Part III.B.
} 
The Case for Open Admission and In-State Tuition Rates for Students Without Lawful Immigration Status. ${ }^{11}$ Specifically, this article focuses on how these developments relate to access to education for our nation's undocumented and DACAmented population. First, the authors examine federal initiatives offering relief to undocumented youths in the United States and the development of the DACA program. Next, the article considers how access to higher education for both undocumented and DACA students is viewed under federal laws. The study concludes by analyzing the intersection and impact of federal advances with a sampling of state laws and policies related to the enrollment and access to resident tuition rates at public universities for DACA and undocumented students.

\section{II. “DREAMERS” AND THE DisTinCTION BETWEEN DACA RECIPIENTS AND UNDOCUMENTED STUDENTS}

\section{A. The Current Status of the DREAM Act}

For more than a decade, a number of federal laws have been proposed that would offer assistance to undocumented students living in the United States. The Development, Relief, and Education of Alien Minors ("DREAM") Act was initially introduced in the Senate in 2001. ${ }^{12}$ The DREAM Act was designed to confer lawful immigration status to certain individuals who entered this country as children and pursued a higher education degree or served in the U.S. military, often referred to as "DREAMers." The term DREAMers may include both DACA and undocumented students; however, DACA and undocumented students are not the same, as explained further below. Since its inception, the DREAM Act has been proposed in a variety of different forms, but has never been passed into law by Congress. In 2013, former House Majority Leader Eric Cantor $^{13}$ proposed the Kids Act, an alternative to the DREAM Act that would provide DREAMers an opportunity to earn a path to citizenship

${ }^{11}$ Thomas R. Ruge \& Angela D. Adams (Iza), Higher Education for

Undocumented Students: The Case for Open Admission and In-State Tuition Rates for Students Without Lawful Immigration Status, 15 InD. INT'L \& COMP. L. REV. 257 (2005). The authors would like to thank Thomas Ruge for his contributions to this article.

${ }^{12}$ S. 1291, 107th Cong. (2001).

${ }^{13}$ On June 10, 2014, Representative Cantor lost the Republican Primary Election to Dave Brat and soon thereafter announced his intention to resign as House Majority Leader, effective July 31, 2014. See Luke Russert \& Frank Thorp, Cantor Announces Resignation As Majority Leader, NBC NEws (June 11, 2014, 1:12 PM), http://perma.cc/BK5Z-PRB8. 
through either college or military service. ${ }^{14}$ Approval of this Act is currently stalled in the House, as representatives continue to debate whether it should permit beneficiaries of the Act to petition for their undocumented parents to gain lawful status through their children. ${ }^{15}$

\section{B. The Distinction between DACA Recipients and Undocumented Students}

DACA, initially announced on June 15, 2012, provides certain individuals who do not have lawful immigration status and who entered the United States as minors with a two-year grant of deferred action; meaning, during that time the Department of Homeland Security ("DHS") will exercise its discretion to forego placing DACA recipients in immigration removal proceedings. ${ }^{16}$ DACA recipients are eligible for employment authorization ${ }^{17}$ and a Social Security number, ${ }^{18}$ and in most states they can obtain a driver's license. ${ }^{19}$

DACA does not grant lawful immigration status to recipients, nor does it provide a pathway to citizenship. ${ }^{20}$ However, under guidelines issued by U.S. Citizenship and Immigration Services ("USCIS”), receipt of DACA does, in fact, make one "lawfully present" ${ }^{21}$ in the United States. ${ }^{22}$ There is a clear distinction between "lawful presence" and "lawful status." An individual is deemed to be unlawfully present in the United States if he or she entered the country without having been admitted or paroled or

${ }^{14}$ Cesar Vargas, Halt Deportation and Pass KIDS Act As Steps to Immigration Reform, THE HILl (Nov. 16, 2013, 9:00 AM), http://perma.cc/4AW7-P64S.

${ }^{15}$ Fawn Johnson, Parent Sponsorship Stalls Kids Act, NAT’L J. (Nov. 3, 2013), http://perma.cc/B493-HAER.

${ }^{16}$ Napolitano Memorandum, supra note 8.

${ }^{17} \mathrm{Id}$.

18 Soc. Sec. Admin., Social Security Number-Deferred Action for CHILDHOOD ARRIVALS, available at http://perma.cc/EEN6-6Y3F.

19 Are Individuals Granted Deferred Action Under the Deferred Action for Childhood Arrivals (DACA) Policy Eligible for State Driver's Licenses? NAT'L IMMIGRATION LAW CTR. (June 19, 2013), http://perma.cc/Y2PE-TC2D.

${ }^{20}$ U.S. DEP’T HOMELAND SEC., U.S. CITIZEN \& IMMIGRATION SERVS., FREQUENTLY ASKED QUESTIONS [hereinafter USCIS FAQ] ("Deferred Action for Childhood Arrivals (DACA) is an exercise of prosecutorial discretion and does not provide lawful status or a pathway to citizenship.”), http://perma.cc/7DN7-M8ZQ.

${ }^{21}$ The concept of lawful presence plays an integral role in examining a student's eligibility for in-state tuition; see discussion infra Parts III and IV.

${ }^{22}$ See USCIS FAQ, supra note 23 ("However, although deferred action does not confer a lawful immigration status, your period of stay is authorized by the Department of Homeland Security while your deferred action is in effect and, for admissibility purposes, you are considered to be lawfully present in the United States during that time.”). 
remains in the country following the expiration of an authorized stay. ${ }^{23}$ Unlawful status, on the other hand, relates to whether or not the individual has violated the terms of his or her previously lawful status by committing a certain act, like a crime or accepting unauthorized employment. ${ }^{24}$ DACA recipients, therefore, find themselves in a unique situation, as they are lawfully present in the United States regardless of their lack of immigration status. However, given the fact DACA is not enacted as law, DHS has the authority to renew or even terminate a DACA grant at any time. Further, because DACA operates by presidential executive authority, the program's continuance depends on the desire of future U.S. Presidents.

In order to qualify for DACA, an undocumented individual must: 1. have entered the United States before his or her sixteenth birthday;

2. have been continuously present in the United States ${ }^{25}$ since June $15,2007^{26}$ and, more specifically, been physically present in the United States on June 15, 2012;

3. be currently enrolled in school, graduated from high school, obtained a General Educational Development (“GED”) certificate, or be enrolled in or have successfully completed another qualifying

23 Immigration and Nationality Act (INA) § 212(a)(9)(B)(ii), 8 U.S.C. § 1182(a)(9)(B)(ii) (2013).

249 Foreign Affairs Manual § 40.92 (2013).

${ }^{25}$ An exception is made for "brief, casual, and innocent" absences from the United States. See U.S. Dep't Homeland Sec., U.S. Citizen \& Immigration Servs., Consideration of Deferred Action for Childhood Arrivals (DACA): Guidelines [hereinafter USCIS, Guidelines], http://perma.cc/N5U3-B8B2 (last updated Feb. 18, 2014).

${ }^{26}$ Id.; Additionally, the reader should note that on November 20, 2014, the Obama Administration announced, among other immigration initiatives, an "expanded" form of DACA that would permit individuals who have been continuously present in the United States since January 1, 2010, rather than June 15, 2007, to apply for DACA benefits that would span a three-year timeframe. Memorandum from Sec'y of Homeland Sec. Jeh Johnson to Leon Rodriguez, Director, U.S. Citizenship and Immigration Services; Thomas S. Winkowski, Acting Director, U.S. Immigration and Customs Enforcement; and R. Gil Kerlikowske, Comm'r, U.S. Customs and Border Prot. (November 20, 2014), available at http://www.dhs.gov/sites/default/files/publications/14_1120_memo_deferred_actio n.pdf. USCIS was scheduled to begin processing applications for expanded DACA on February 18, 2015; however, in light of a recent preliminary injunction issued by the Southern District of Texas, the Service has placed a hold on processing said applications pending the resolution of the federal lawsuit. See http://pdfserver.amlaw.com/nlj/texas_immigration_20150216.pdf. See also Julia Preston, Obama Immigration Policy Halted by Federal Judge in Texas, NY TIMES (Feb. 17, 2015), http://www.nytimes.com/2015/02/18/us/obama-immigrationpolicy-halted-by-federal-judge-in-texas.html. 
educational program (e.g., GED preparatory course and/or English as a second language course);

4. be at least fifteen years old at the time of the application, ${ }^{27}$ but not more than thirty as of June 15, 2012; and

5. have never been convicted of a felony, significant misdemeanor, ${ }^{28}$ or more than three non-significant misdemeanors, and not pose a national security or public safety threat.

The implementation of the DACA program grants those to which it applies authorization to work and remain in the United States. Some would therefore say that DACA recipients are no longer "undocumented" because they have been determined by the federal government to be lawfully present in the United States, irrespective of their immigration status.

\section{Federal Laws Addressing Higher Education for Undocumented and DACA Students}

\section{A. Existing Federal Laws Do Not Prohibit Enrollment of DACA and Undocumented Students}

Federal law neither prohibits undocumented or DACA students from enrolling in public postsecondary educational institutions nor entitles them to such a right. In Plyler v. Doe, the Supreme Court of the United States examined the constitutionality of a Texas statute that withheld "from local school districts any state funds for the education of children who were not 'legally admitted' into the United States, and which authorize[d] local school districts to deny enrollment to such children." 29 Relying on the Equal Protection Clause of the Fourteenth Amendment, the Court ruled that a state cannot deny a free public education from kindergarten through twelfth grade to undocumented immigrant students who are residing in a school district, as there was no empirical evidence to demonstrate that the policy would further a substantial state interest. The Court ultimately held that states must guarantee to children free public school access to a primary

${ }^{27}$ DHS provides for an exception of this minimum age requirement for individuals who are under the age of fifteen and have previously been in removal proceedings. See id.

${ }^{28}$ A significant misdemeanor includes an offense for which an individual was sentenced to, and actually spent, more than ninety (90) days in custody. USCIS, Guidelines, http://perma.cc/N5U3-B8B2 (last updated Feb. 11, 2015). Additionally, offenses of domestic violence, sexual abuse, burglary, unlawful possession or use of a firearm, drug distribution or trafficking, or, driving under the influence are also considered significant misdemeanors, regardless of the sentence imposed. Id.

${ }^{29}$ Plyler v. Doe, 457 U.S. 202, 205 (1982) (5-4 decision) (Burger, C.J., dissenting). 
and secondary education, regardless of their immigration status. ${ }^{30}$ This holding neither extends nor prohibits the same protections to higher education.

There are very few cases specifically addressing the question of admission of undocumented students into institutions of higher education. For example, in Equal Access Education v. Merten, the U.S. District Court for the Eastern District of Virginia addressed whether states could deny admission to undocumented students. ${ }^{31}$ The court held that, under the Supremacy Clause of the U.S. Constitution, admissions policies must include federal immigration standards for determining the immigration status of college applicants. ${ }^{32}$ In recognizing the absence of federal law addressing the admission of undocumented students to public institutions of higher education, the court upheld Virginia's policy of precluding undocumented students from enrolling. ${ }^{33}$

\section{B. Granting Resident Tuition Rates to DACA and Undocumented Students is Not Contrary to Federal Law and is within States' Discretion}

The Illegal Immigration Reform and Immigrant Responsibility Act (“IIRIRA”), codified at 8 U.S.C. §1623(a), prohibits public postsecondary educational institutions from providing any "alien who is not lawfully present in the United States" with a postsecondary education benefit, "unless a citizen or national of the United States is eligible for such a benefit . . . without regard to whether the citizen or national is such a resident." ${ }^{34}$ Because DACA students are lawfully present in the United States, ${ }^{35}$ this federal law does not apply to them. While there are no federal regulations interpreting these statutes as applied to undocumented students, a plain reading shows no prohibition of lower tuition rates based on a uniformly applied residency or other requirement. The use of the word "unless" suggests that states have the power to determine residency for undocumented immigrant students. The statute simply conveys that a state or institution cannot give additional consideration to an undocumented student that it would not give to a U.S. citizen.

The Personal Responsibility and Work Opportunity Reconciliation Act of 1996 ("PRWORA”), codified at 8 U.S.C \$1611, provides that foreign nationals who are not "qualified aliens" are ineligible to receive public benefits. Although DACA and undocumented students do not fit the

\footnotetext{
${ }^{30}$ Id at 230.

${ }^{31}$ Equal Access Education v. Merten, 305 F. Supp. 2d 585 (E.D. Va. 2004).

${ }^{32} \mathrm{Id}$. at 608 . For extended discussion and analysis of cases addressing enrollment of undocumented students, see Ruge \& Iza, supra note 14, at 264-66.

${ }^{33}$ Merten, 305 F. Supp. 2d at 614.

348 U.S.C. § 1623(a) (2013).

35 USCIS FAQ, supra note 25.
} 
statutory definition of "qualified aliens," 36 a careful examination of the definition of "public benefit" reveals that federal law does not prohibit offering in-state tuition rates to undocumented and DACA students. The U.S. Code provides a list of what qualifies as a "state or local public benefit," which includes "postsecondary education . . . for which payments or assistance are provided to an individual." ${ }^{37}$ A number of courts have held that the definition of public benefits under 8 U.S.C. §1621 and §1623 refers to monetary benefits and not the granting of in-state tuition rates. ${ }^{38}$ Other courts have asserted that Congress never intended to prohibit states from providing in-state tuition to foreign nationals, because it would have written $\$ 1623$ differently had it intended to do so. ${ }^{39}$ Under 8 U.S.C. §1621(d), states have the authority to enact laws that determine the eligibility of foreign national students for certain state and local benefits. ${ }^{40}$ The Supreme Court of the United States has also held that states have the discretionary power to regulate tuition for publicly-funded schools. ${ }^{41}$ The Court has remarked that public education is not "merely some governmental 'benefit' indistinguishable from other forms of public welfare." 42 Therefore, federal law does not prohibit DACA and undocumented students from receiving in-state tuition rates, and states have discretion to enact laws in this area.

\section{Federal Law Restricts Federal and State Financial Aid to DACA and Undocumented Students but Gives States Authority}

The statutes discussed above prohibit DACA and undocumented students from receiving federal and state financial aid as they would not be considered "qualified aliens." ${ }^{43}$ In addition, financial aid would likely be considered a "state or local public benefit,” which 8 U.S.C. \$1621 defines as:

(a) any grant, contract, loan, professional license or

\footnotetext{
${ }^{36}$ Among other categories, qualified aliens are those with lawful permanent resident status, asylees, and refugees. See 8 U.S.C. § 1641(b).

${ }^{37}$ See 8 U.S.C. $\S 1623(\mathrm{c})(1)(\mathrm{B})$ (emphasis added).

${ }^{38}$ See Merten, 305 F. Supp. 2d at 607; see also County of Alameda v. Agustin, 2007 Cal. App. Unpub. Lexis 7665, at*10 (1st App. Dist. Sept. 24, 2007).

${ }^{39}$ See Martinez v. Regents of the Univ. of California, 50 Cal.4th 1277, 241 P.3d 855, 117 Cal.Rptr.3d 359 (Cal., 2010).

408 U.S.C. \$1621(d).

${ }^{41}$ See DeCanas v. Bica, 424 U.S. 351, 358 (1976), superseded by statute, Immigration Reform and Control Act of 1986 (IRCA), Pub. L. No. 99-603, 100 Stat. 3359, as recognized in Chamber of Commerce of the United States v. Whiting, 131 S.Ct. 1968, 1975 (2011).

${ }^{42}$ See Plyler v. Doe, 457 U.S. 202, 221 (1982).

${ }^{43} 8$ U.S.C. §1641(b).
} 
commercial license provided by an agency of a State or local government or by appropriate funds of a State or local government; and (b) any retirement, welfare, health, disability, public or assisted housing, postsecondary education, food assistant, unemployment benefit, or any other similar benefit for which payments or assistance are provided to an individual, household, or family eligibility unit by an agency of a State or local government or by appropriated funds of a State or local government. ${ }^{44}$

However, under 8 U.S.C. $\$ 1621(d)$, states retain the authority to provide state and local public benefits to "an alien who is not lawfully present in the United States." ${ }^{45}$ Under this provision, five states have passed legislation allowing undocumented students to qualify for state financial aid. ${ }^{46}$ Absent state legislation, these existing federal restrictions laid out in 8 U.S.C. would likely prohibit a state or institution from granting state funded financial aid to DACA and undocumented students.

\section{State Approaches Increasing Access to Postsecondary Education for Daca and Undocumented Students}

Below is a sampling of a variety of state laws, referendums, and policies outlining states' stances on providing in-state tuition to undocumented students and, more specifically, DACA recipients. Also included is an overview of a number of state and federal cases interpreting the constitutionality of state-led initiatives granting in-state tuition rates to undocumented students.

\section{A. State Legislation and Polices Regarding Eligibility for Resident Tuition} Rates

While only five states currently allow undocumented students to qualify for state financial aid, ${ }^{47}$ at least twenty-one states-California, Colorado, Connecticut, Florida, Hawaii, Illinois, Indiana, Kansas, Maryland, Michigan, Minnesota, Nebraska, New Jersey, New Mexico, Oklahoma, Oregon, Rhode Island, Texas, Utah, Virginia, and Washington-have implemented legislation or other policy initiatives

448 U.S.C. $\$ 1621(c)$.

458 U.S.C. $\$ 1621(\mathrm{~d})$.

46 Undocumented Student Tuition: State Action, NAT'L Conf. STATE Legislatures (June 12, 2014), http://perma.cc/M29C-B9H3 (listing California, Minnesota, New Mexico, Texas, and Washington as the only states that currently allow undocumented students to receive state financial aid).

${ }^{47} \mathrm{Id}$. 
classifying DACA and undocumented students as eligible recipients of instate tuition rates. ${ }^{48}$ These policy measures include a wide range of residency and high school attendance or graduation requirements, and some states require students to sign an affidavit promising to seek legal immigration status. ${ }^{49}$ Some states reserve this benefit for DACA recipients only, requiring undocumented students to pay out-of-state tuition. Below is a sampling of recent state policies that qualify undocumented or DACA students for enrollment and resident tuition rates at state public colleges and universities.

Virginia: Virginia previously espoused the view that "section 505 of IIRIRA prohibited states from offering in-state tuition to undocumented immigrants unless the same is provided equally to all citizens." ${ }^{50}$ However, the state has seen a number of recent policy developments regarding access to in-state tuition rates for undocumented students. In January 2014, Virginia State Senator Donald McEachin introduced Senate Bill 249, proposing in-state tuition rates for DACA recipients if they, or their parents, could demonstrate having filed state taxes for three or more years. ${ }^{51}$ However, this bill failed to pass the Senate Education and Health Committee. ${ }^{52}$ Recently, Virginia Attorney General Mark Herring issued a memorandum to the State Council of Higher Education, the presidents of Virginia's colleges and universities, and the chancellors of the Virginia Community College System, asserting that DACA recipients are eligible to pay the resident tuition rate under the existing state law. ${ }^{53}$ Virginia Code §23-7.4 lays out the resident tuition rate qualifications, focusing primarily on domiciliary requirements. Like other students looking to pay in-state tuition rates, DACA students must demonstrate that they (1) have a fixed place of residence in Virginia, (2) have maintained a domicile in the state for

48 State Laws and Policies, NAT’L Immigration LAw CTR. (June 9, 2014), http://perma.cc/J36A-UN8Y; Letter from Mark R. Herring, Att'y Gen. for the Commonwealth of Va. (Apr. 29, 2014), available at http://perma.cc/J47A-STNC; Basic Facts about In-State Tuition for Undocumented Immigrant Students, NAT'L IMMIGRATION LAW CTR. (June 2014), http://perma.cc/9MWZ-YAXS.

${ }^{49}$ Basic Facts, supra note 50.

${ }^{50}$ Ruge \& Iza, supra note 14, at 272.

${ }^{51}$ State Bills on Access to Education for Immigrants, NAT'L IMMIGRATION LAW CTR. (September 29, 2014), http://perma.cc/W45V-N4FS.

52 S. 249, 2014 Va. Gen. Assemb. Reg. Sess. (Va. 2014), available at http://perma.cc/6DDA-X533.

${ }^{53}$ Herring, supra note, 50. 
at least one year following receipt of DACA, and (3) intend to remain there indefinitely. ${ }^{54}$

Florida: On May 2, 2014, the Florida House of Representatives passed House Bill 851 and Florida Governor Rick Scott signed the bill into law on June 9, 2014. ${ }^{55}$ The new measure requires state colleges, universities, and charter technical career centers to offer in-state tuition to "students who are undocumented for federal immigration purposes” and who: (1) attended a Florida secondary school at least three years before graduating from a state high school, (2) apply for admission to a state postsecondary educational institution within twenty-four months of high school graduation, and (3) provide that institution with an official Florida high school transcript. ${ }^{56}$

Indiana: On July 1, 2011, the Indiana General Assembly enacted House Bill 1402, which restricts individuals "not lawfully present in the United States" ${ }^{57}$ from qualifying for resident tuition rates at public universities. A separate law, Senate Enrolled Act 590 ("SEA 590"), went into effect on July 1, 2011, and requires a state agency to verify the eligibility of an applicant for public benefits. ${ }^{58}$ SEA 590 states "the term 'state or local public benefit' has the meaning set forth in 8 U.S.C. 1621" and "includes (1) a postsecondary education award, including a scholarship, a grant, or financial aid; and (2) the resident tuition rate (as determined by the state educational institution)." ${ }^{\text {"I }}$ Indiana Code 24-14-11-1 restricts in-state tuition eligibility to those lawfully present in the United States. However, under Senate Bill 207, which passed into law on May 7, 2013, this restriction does not apply to individuals enrolled in state educational institutions on or before July 1 , $2011 .^{60}$

\section{B. Case Law Addressing In-State Tuition Rate Eligibility}

Various state and federal courts have found that offering resident

${ }^{54} \mathrm{Id}$.

${ }^{55}$ H.R. 851, 2014 Leg., Reg. Sess. (Fla. 2014) (enacted), available at http://perma.cc/8XVR-LFXS.

${ }^{56}$ Fla. Stat. § 1009.26(12)(a) (2014), available at http://perma.cc/CCD9-R5BU.

${ }^{57}$ Ind. Code $\S 21-14-11-1($ a) (2011) (emphasis added).

${ }^{58}$ Ind. Code $\S 12-32-1-3$ (2014).

${ }^{59} \mathrm{Id}$.

${ }^{60}$ Ind. Code $§ 12-32-1-5(d)(3)$. 
tuition rates to undocumented students does not violate federal law. In Day $v$. Sebelius and Martinez v. Regents of the University of California, plaintiffs challenged laws granting in-state tuition to undocumented students in Kansas and California, respectively. ${ }^{61}$ In both cases, the plaintiffs argued that the legislation violated federal immigration laws and the Equal Protection Clause. Both cases were dismissed on the grounds that the plaintiffs failed to prove that the law injured them personally. In Martinez, the appellate court overturned the lower court's dismissal, ruling that the California statute granting in-state tuition to undocumented students violated federal law. However, in a unanimous decision, the California Supreme Court reversed the appellate court's ruling, asserting that since individuals do not qualify for in-state tuition at a California public college or university based on residence, but rather, on attendance and graduation from a state high school, the statute did not violate federal law. ${ }^{62}$ The U.S. Supreme Court refused to hear an appeal from this decision. ${ }^{63}$ As it stands, there is no law that prohibits states from allowing undocumented or DACA students to qualify for resident tuition rates.

\section{The Continuing Debate Over Access to Higher Education for "DACAmented" and Undocumented Students}

With no federal law in place either providing for or prohibiting undocumented and DACA students from enrolling in or receiving in-state tuition for public postsecondary educational institutions, ${ }^{64}$ state policy initiatives are in limbo. Efforts by several states to restrict enrollment and resident tuition rates are being challenged, but the issues remain unresolved. The following examples illustrate the unsettled nature of these issues.

Georgia: In October 2010, the Board of Regents of the University System of Georgia ("USGBOR”) adopted Policy 4.1.6, which states that "[a] person who is not lawfully present in the United States shall not be eligible for admission to any University System Institution which, for the two most recent academic years, did not admit all academically qualified applicants (except for cases in which applicants

${ }^{61}$ Day v. Sebelius, 376 F. Supp. 2d 1022 (D.Kan. 2005); Martinez v. Regents of the Univ. of Cal., 241 P.3d 855, 859 (Cal. 2010).

62 Josh Keller, California Supreme Court Upholds Law Giving In-State Tuition to Illegal Immigrants, CHRON. HigheR EdUC. (Nov. 15, 2010), http://perma.cc/8P2PR67.

${ }^{63}$ Bill Mears, Supreme Court: State Can Offer Illegal Immigrants Reduced Tuition, CNN (June 6, 2011), http://perma.cc/R54P-XC7F.

${ }^{64}$ See discussion of Plyler, supra Part III.A. 
were rejected for non-academic reasons)." ${ }^{65}$ According to the USGBOR policies, DACA students are not recognized as being lawfully present in the United States and, consequently, undocumented and DACA students are ineligible to attend the state's top-five state universities. ${ }^{66}$ This policy prompted thirty-nine DACA recipients to file suit in Dekalb County Superior Court against the USGBOR. ${ }^{67}$ The Court ultimately dismissed the suit, concluding USGBOR qualified for sovereign immunity. ${ }^{68}$ The Court therefore could not properly rule on the central issue of whether DACA recipients are "lawfully in [the] state." 69 The Court noted "[t]he fact that judicial review is not available to resolve this issue is lamentable." ${ }^{70} \mathrm{An}$ appeal of this decision was filed with Georgia's Supreme Court in August 2014 and is currently pending. ${ }^{71}$

Alabama: In 2011, the Alabama legislature passed House Bill 56 into law, which contains a series of prohibitions affecting the daily lives of the state's undocumented population. ${ }^{72}$ The measure included a prohibition on the enrollment of an "alien who is not lawfully present in the United States" in any state public postsecondary educational institution. ${ }^{73}$ The ACLU filed suit challenging the constitutionality of

65 BD. Regents of the Univ. Sys. of Ga., Policy Manual § 4.16 (Oct. 29, 2010), available at http://perma.cc/H4VP-YP4E; see also KARA UMANA, Ultimate Guide For College Bound Undocumented GeORGia STUdents 11 (Matt Hicks ed., 2014), available at http://perma.cc/MDX5-ZRHY.

${ }^{66}$ Deferred Action for Childhood Arrivals (DACA), GA. STATE UnIV. OfFiCE OF UNDERGRAD. ADMISSION (2014), http://perma.cc/CXM7-BZHG.

${ }^{67}$ DACA Recipients and the Right to In-State Tuition: Litigation Commences in Arizona and Georgia, CATHOLIC LEgAL IMMigRATION NETWORK, InC. (Aug. 2013), http://perma.cc/Y2UU-SX66.

${ }^{68}$ DACA Beneficiary Ga. Coll. Students v. Univ. Sys. of Georgia’s Bd. of Regents, 2014 AILA InfoNet Doc. 14061050 (Super. Ct. Fulton County, Ga June 9, 2014).

${ }^{69} \mathrm{Id}$.

${ }^{70} \mathrm{Id}$.

${ }^{71}$ E-mail from Charles Kuck, Attorney for Plaintiffs, to Author (June 30, 2014) (on file with the author); See also, Michael A. Olivas, "State and federal cases involving Higher Education and immigration, 2004- 2014 and all cases citing Sections 1621/1623 (by current citation)," University of Houston Law Center, http://www.law.uh.edu/ihelg/documents/Cases2004-

2014cases1621_1623/homepage.asp.

${ }^{72}$ H.R. 56, Ala. H. Rep. (Ala. 2011) (enacted), available at http://perma.cc/6F5HSJ2 (making it illegal for undocumented residents to engage in business transactions; negating contracts entered into by unauthorized immigrants; and making it illegal for unauthorized immigrants to look for work).

${ }^{73} I d$. 
the law, which resulted in a settlement agreement effectively removing several provisions. Although the bar on undocumented enrollment remains in effect, Alabama law permits DACA students to enroll and pay resident tuition. $^{74}$

New York: In 2013, legislators in New York proposed Assembly Bill 2463 ("A02463"), which is currently being held for consideration by the New York Senate Standing Committee on Higher Education. If passed into law, A02463 will prohibit the admission of any person who is not a U.S. citizen, a lawful permanent resident, an alien lawfully admitted to the United States for a temporary period of time, or a person authorized to remain in the United States temporarily under federal law to public colleges. Moreover, this bill instructs admissions officers to report any applicants or students "determined to be, or who [are] under reasonable suspicion of being, in the United States in violation of federal immigration laws" to U.S. Immigrations and Customs Enforcement and other officials. Since this proposed bill would permit "a person authorized to remain in the United States temporarily under federal law," it remains unclear whether A02463 would apply to DACA students who are "lawfully present" in the United States according to USCIS. ${ }^{75}$

Arizona: In 2006, Arizona voters approved the legislative ballot referendum Proposition 300, which amended Arizona Revised Statute Section 15-1803. ${ }^{76}$ Under Proposition 300:

a person who is not a citizen of the United States, who is without lawful immigration status and who is enrolled as a student at any university under the

\footnotetext{
${ }^{74}$ Ala. Code $\S 16-64-2$ (2014); Tuition and State Aid Equity for Undocumented Students and DACA Grantees, UniteDDREAM.ORG (May 2014), http://perma.cc/J6DD-WHC6.

${ }^{75}$ B. A02463, 2013-14 Reg. Sess. (N.Y. 2013), available at http://perma.cc/YQ7GNKLE.

${ }^{76}$ S. Con. Res. 1031, 47th Leg., 2d Reg. Sess. (Ariz. 2006), Ariz. Rev. Stat. § 151803(B), available at http://perma.cc/QSP5-A8YH ("In accordance with the illegal immigration reform and immigrant responsibility act of 1996 (P.L. 104-208; 110 Stat. 3009), a person who was not a citizen or legal resident of the United States or who is without lawful immigration status is not entitled to classification as an instate student pursuant to section 15-1802 or entitled to classification as a county resident pursuant to section 15-1802.01.”).
} 
jurisdiction of the Arizona Board of Regents or at any community college under the jurisdiction of a community college district in [Arizona] is not entitled to tuition waivers, fee waivers, grants, scholarship assistance, financial aid, tuition assistance or any other type of financial assistance that is subsidized or paid in whole or in part with state monies. ${ }^{77}$

Additionally, this proposition requires colleges to report data on the number of students denied in-state tuition rates "because the applicant was not a citizen or legal resident of the United States or was not otherwise lawfully present in the United States." ${ }^{78}$

Following the implementations of DACA in August 2012, Governor Jan Brewer issued Executive Order 2012-06, ReAffirming Intent of Arizona Law In Response to the Federal Government's Deferred Action Program. The Executive Order stipulated that access to state and local public benefits is limited under Arizona Revised Statutes §§ I-501-502 to "persons demonstrating lawful presence in the United States." 79 Governor Brewer expressed her concern that receipt of DACA "could result in some unlawfully present aliens inappropriately gaining access to public benefits contrary to the intent of Arizona voters and lawmakers who enacted laws expressly restricting access to taxpayer funded benefits and state identification." 80 Governor Brewer categorized access to resident tuition rates as a public benefit and asserted that DACA recipients were not lawfully present in the United States.

Despite the executive order, several colleges within the Maricopa County Community College District permitted DACA students who presented evidence of valid employment authorization to pay in-state tuition rates, asserting their work permits "are an acceptable proof of in-state residency." 81 This action led Arizona Attorney General Tom Horne to sue Maricopa County Community College District in June 2013, asserting that university policies allowing DACA students to

${ }^{77}$ Id.

${ }^{78}$ S. Con. Res. 1031, Ariz. Rev. Stat. §15-232(C).

${ }^{79}$ Office of the Ariz. Governor, Exec. Order No. 2012-06, (Aug. 15, 2012), available at http://perma.cc/B5QP-457N.

${ }^{80} \mathrm{Id}$.

${ }^{81}$ Mary Beth Faller, In-state Tuition Lawsuit Against Maricopa Colleges to Proceed, AZ CENTRAL (May 2, 2014), http://perma.cc/AZB4-QPYK. 
pay in-state tuition rates stood in direct violation of Proposition 300, Executive Order 2012-06, and federal law. ${ }^{82}$ The suit is now pending resolution and oral arguments will be heard in the Maricopa County Superior Court on March 6, 2015. ${ }^{83}$

The above-referenced policies and statutes demonstrate that, despite the clear difference between undocumented and DACA students, the question of how to interpret a grant of DACA in terms of admissions and in-state tuition eligibility requirements remains unresolved in many states.

\section{CONCLUSION}

The implementation of the DACA program offered hope for DREAMers who have seen the failure of numerous federal legislative measures that would grant them lawful immigration status in the United States. Separately, states have implemented a variety of laws and policies in an attempt to clarify eligibility of undocumented and DACA recipients for enrollment in postsecondary education and resident tuition rates. This has led to many unresolved issues confronted by state legislative, judicial, and academic officials. Final resolution of these questions will provide clarity to not only thousands of DACA students, but also the universities that they may attend.

${ }^{82}$ DACA Recipients, supra note 69.

${ }^{83}$ Hearing set for arguments in Arizona Immigrant-tuition case, TIMES UNION, (Feb. 4, 2014), http://www.timesunion.com/news/article/Hearing-set-for-arguments -in-Arizona-6061119.php. 